\title{
Community structure and seasonal changes in population structure of pelagic polychaetes collected by sediment traps moored in the subarctic and subtropical western North Pacific Ocean
}

\author{
KANAKO AMEI ${ }^{1, *}$, NAOTO JIMI $^{2}$, MINORU KITAMURA $^{3}$, NAOYA YOKOI $^{4} \&$ ATSUSHI YAMAGUCHI ${ }^{4,5}$ \\ ${ }^{1}$ Faculty of Fisheries, Hokkaido University, 3-1-1 Minato-cho, Hakodate, Hokkaido 041-8611, Japan \\ "”kanakoamei@eis.hokudai.ac.jp, @ https://orcid.org/0000-0003-0418-0988 \\ ${ }^{2}$ Bioscience Group, National Institute of Polar Research, 10-3, Midori-cho, Tachikawa, Tokyo 190-8518, Japan \\ ”- beniimo7010@gmail.com, @ https://orcid.org/0000-0001-8586-3320 \\ ${ }^{3} J a p a n$ Agency for Marine-Earth Science and Technology, 2-15 Natsushima-cho, Yokosuka, Kanagawa 237-0061, Japan \\ ”"kitamura@jamstec.go.jp, @ ittps://orcid.org/0000-0002-8062-8177 \\ ${ }^{4}$ Graduate School of Fisheries Science, Hokkaido University, 3-1-1 Minato-cho, Hakodate, Hokkaido 041-8611, Japan \\ ”naoya.yokoi@gmail.com \\ ${ }^{5}$ Arctic Research Center, Hokkaido University, Kita-21 Nishi-11 Kita-ku, Sapporo, Hokkaido 001-0021, Japan \\ झ"a-yama@fish.hokudai.ac.jp, (1) https://orcid.org/0000-0002-5646-3608 \\ *Correspondence: "kanakoamei@eis.hokudai.ac.jp
}

\begin{abstract}
Community structure and seasonal changes in the population structure of pelagic polychaetes were studied based on zooplankton samples collected by sediment traps moored at $200 \mathrm{~m}$ depth in the subarctic and subtropical western North Pacific throughout the year. Eight species belonging to seven genera and seven families occurred at the subarctic station, while twelve species belonging to ten genera and seven families were identified at the subtropical station. Polychaete abundance was $5.37 \pm 0.44$ ind. $\mathrm{m}^{-2}$ day ${ }^{-1}$ (annual mean \pm standard error) at the subarctic station, and $1.36 \pm 0.15$ ind. $\mathrm{m}^{-2}$ day $^{-1}$ at the subtropical station. Polychaete abundance at the subarctic station was high from May to August, but no seasonal patterns were observed at the subtropical station. The dominant species in the subarctic was Tomopteris septentrionalis, which accounted for $62.9 \%$ of annual mean abundance; at the subtropical station, the dominant species was Pelagobia sp. (22.8\%). In the subarctic, small specimens of T. septentrionalis ( $<3 \mathrm{~mm}$ in body length) occurred only in winter (December-March). No clear seasonal changes in population structure of the subtropical Pelagobia sp. were detected. The latitudinal patterns we observed in the polychaete communities of the western North Pacific were similar to those previously observed in the eastern North Pacific. Changes in the population structure of T. septentrionalis suggest that the life cycle of this species is seasonal in the subarctic region.
\end{abstract}

\section{Introduction}

Pelagic polychaetes play important roles in food webs and in material fluxes in oceanic marine ecosystems (Jumars et al. 2015; Halanych et al. 2017). The pelagic polychaete Pelagobia longicirrata Greeff, 1879, for example, is reported to be a herbivore (Day 1967; Hopkins 1985, 1987; Hopkins \& Torres 1989), and is known to be the prey of various taxa such as copepods and amphipods (Hopkins 1985; 1987). Polychaetes (mainly P. longicirrata) account for $34 \%$ of the prey items consumed by the carnivorous chaetognath Pseudosagitta gazellae (Ritter-Záhony, 1909) (Øresland 1990). Some carnivorous polychaetes such as Tomopteris (Lebour 1923; Rakusa-Suszczewski 1968; Fauchald \& Jumars 1979) and Typhloscolex (Feigenbaum 1979) are known to feed on chaetognaths. Poeobius meseres Heath, 1930 creates a mucus web in the water column, passively collecting detrital particles on the web and then feeding on it with its ciliated tentacles (Uttal \& Buck 1996). Thus, the feeding modes of pelagic polychaetes are varied, and they may have an important role in the food web and organic matter fluxes in the pelagic ecosystem.

Despite their importance, information about the ecology and life histories of pelagic polychaetes is scarce. 
Most information about polychaete reproduction, development and life cycles concerns benthic species living in the neritic region (cf. Giangrande 1997 and references therein). For the pelagic realm, most ecological information on polychaetes concern planktonic larval stages in the neritic zones (cf. Blake 2017 and references therein). Thus, most ecological information on polychaetes is derived from the neritic region, and limited ecological information is available for pelagic polychaetes (Halanych et al. 2007).

The paucity of ecological information (especially on seasonal patterns in abundance and on life cycles) for oceanic pelagic polychaetes may due to the lack of sufficient sampling to collect seasonal time-series samples. Few attempts have been made to collect seasonal time-series samples of polychaetes in the oceanic region (cf. Accornero et al. 2003; Guglielmo et al. 2014). One method to collect such samples is by using automated sediment traps, which collect passively settling particles in an exposed sample cup for a certain period of time, then rotate to close that cup and expose a new one. Such traps can be moored in the field where they collect multiple samples over the course of a year. Such samples have previously been used to estimate growth rates and describe the life cycles of oceanic copepods and chaetognaths (Ohashi et al. 2011; Matsuno et al. 2014). Though they may be very useful for studying pelagic polychaetes, as well, few attempts have been made to use sediment traps for this purpose (Accornero et al. 2003).

In the present study, we evaluate community structure and seasonal changes in the population structure of pelagic polychaetes based on zooplankton swimmer samples collected by sediment traps moored at 200 $m$ depths of the subarctic and subtropical western North Pacific throughout the year. For the most dominant species in each region, body length and segment numbers were quantified, and their seasonal changes were evaluated. We compare data we obtained on polychaete community structure in the western North Pacific with data from the eastern North Pacific (California Current System) (Fernández-Alamo et al. 2003). Based on seasonality in population structure, we identify some features of the life cycles of the dominant species.

\section{Methods}

\section{Sampling location}

With the goal of quantitatively evaluating carbon and material cycles, the Japan Agency for Marine-Earth Science and Technology (JAMSTEC) established two time-series sites in the western Pacific, one in the subarctic gyre (St. K2: $47^{\circ} 00^{\prime} \mathrm{N}, 160^{\circ} 00^{\prime} \mathrm{E}$, bottom depth: $5200 \mathrm{~m}$ ), and one in the subtropical gyre (St. S1: $30^{\circ} 00^{\prime} \mathrm{N}$, $145^{\circ} 00^{\prime} \mathrm{E}$, bottom depth: $5700 \mathrm{~m}$ ). As part of the "K2S1" project, JAMSTEC scientists have conducted timeseries sampling at these sites since 2010 (Honda 2016). Preliminary cruise reports and metadata from the K2S1 project are available from JAMSTEC "DARWIN" database (http://www.godac.jamstec.go.jp/darwin/e), and environmental data such as dissolved oxygen, nutrients, chlorophyll and fluxes of settling particles are available from the "K2S1 Database" (https://ebcrpa.jamstec.go.jp/k2s1/en/).

\section{Sample collection}

Samples were collected using time-series sediment traps (SMD26S-26 with 26 collecting cups, conical-shaped, and an open mouth area of $0.5 \mathrm{~m}^{2}$; Nichiyu Giken Kogyo Co., Ltd., Kawagoe, Japan). These were moored at a depth of $200 \mathrm{~m}$ at both subarctic (St. K2) and subtropical (St. S1) sites from 25 July 2013 to 15 May 2014 (St. K2) and 18 July 2013 to 4 July 2014 (St. S1) (Fig. 1). The traps were anchored with rope to the sea floor at each station. A solution of $10 \%$ buffered formalin seawater was added to each trap cup before deployment. Each sample cup was exposed for 7 or 14 days at St. K2, and 9 or 18 days at St. S1. After recovery, collected samples were gently sieved on to a 1-mm mesh, and the fraction captured on the mesh ( $\geq 1 \mathrm{~mm})$ was examined. Note that samples were unavailable at St. K2 from 3 April to 1 May 2014. For details on the abundance of the rest of the zooplankton community and on the abundance of particles $<1 \mathrm{~mm}$ in size, see Yokoi et al. (2018) and Honda et al. (2016), respectively.

\section{Polychaetes}

Pelagic polychaetes were sorted from whole zooplankton swimmer samples, identified to the lowest level possible under a stereomicroscope, and counted. Identifications were made using Dales (1957). Polychaete abundance (ind. $\mathrm{m}^{-2}$ day $^{-1}$ ) was calculated using the following equation:

Abundance $=N / 0.5 / D$

where $N$ is the number per sample (ind. sample $\left.{ }^{-1}\right), 0.5$ is the mouth area $\left(\mathrm{m}^{2}\right)$ of the sediment trap, and $D$ is the length of time over which the trap sample was captured (day). 
To evaluate seasonal changes in polychaete abundance, abundance data were log-transformed $(\log [X+1])$ to reduce bias due to quantitative redundancy. Similarities between samples were identified using the BrayCurtis method. To group the samples, similarity indices were coupled with hierarchical agglomerative clustering using an unweighted pair group method using the arithmetic mean. For detailed methods, see Yokoi et al. (2018) and references therein.

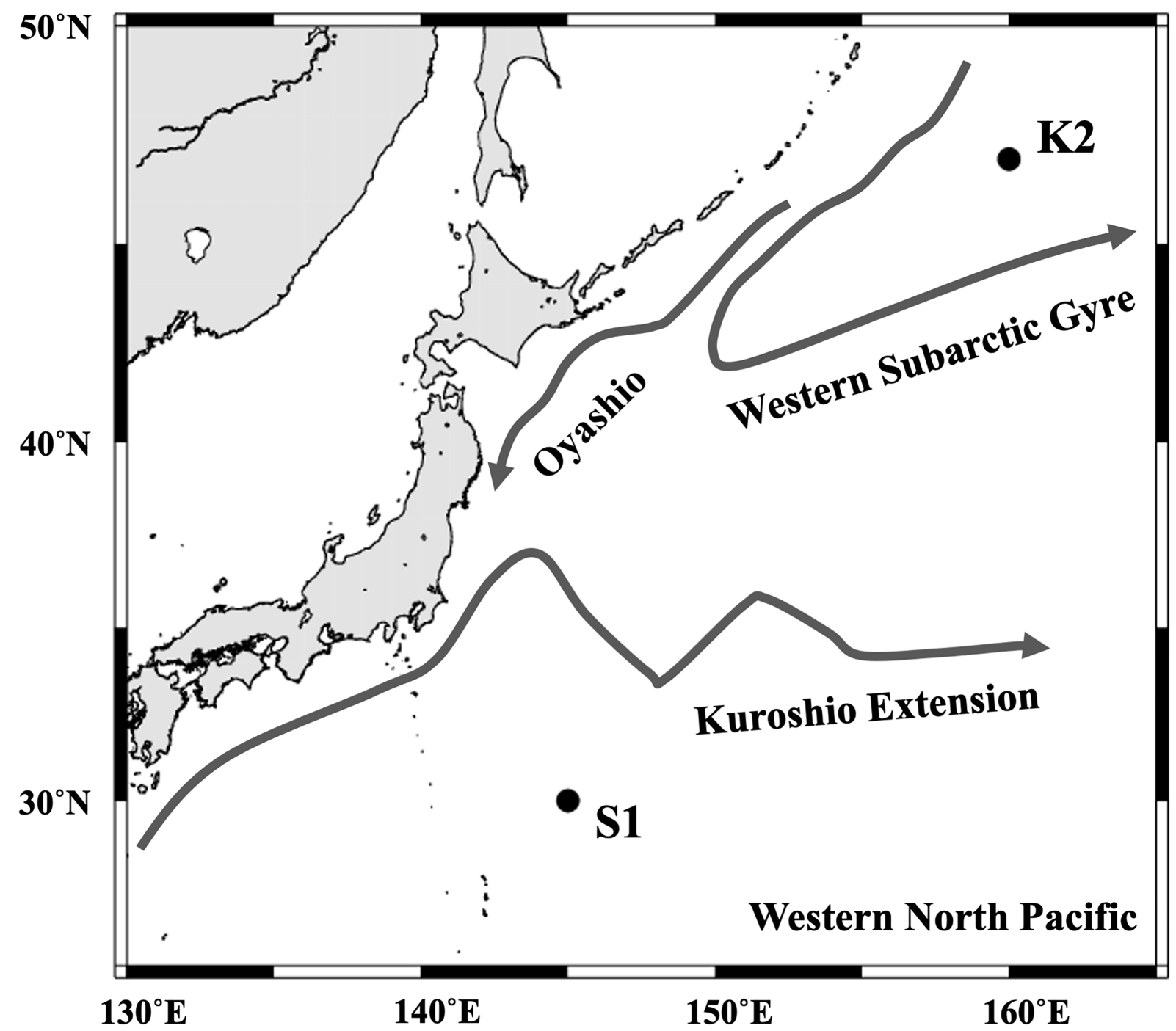

FIGURE 1. Location of sampling stations. K2 is in the subarctic and S1 is in the subtropical western North Pacific. The approximate directions of current flows are shown with arrows (Yasuda 2003).

For the dominant species at each station (Tomopteris septentrionalis Steenstrup, 1849 at St. K2 and Pelagobia sp. at St. S1), body length was measured from the tip of prostomium to end of the anal cirrus by the aid of an eye-piece micrometer or calipers, with a precision of $0.1 \mathrm{~mm}$. Body length data for each month were pooled within season: spring (approximately April to June, slightly varied with the station), summer (JulySeptember), autumn (October-December), and winter (January-March), and histograms of size structure were made. Since body length of $T$. septentrionalis had a normal distribution ( $p<0.05$, Kolmogorov-Smirnov test), seasonal differences in body length were tested by one-way ANOVA and post-hoc test (Tukey-Kramer). For Pelagobia sp., body length was not normally distributed ( $p>0.05$, Kolmogorov-Smirnov test), so seasonality in body length was evaluated by the Welch test. 


\section{Results}

\section{Polychaete species composition}

A total of 572 individual pelagic polychaetes were collected at the two stations across the sampling period. At the subarctic station (K2) a total of 10 species were collected, in seven families. Eight of these were identified as members of seven genera; two were identified only to the family level. At the subtropical station (S1), a total of 16 species were collected, in seven families. Twelve of these were identified as members of ten genera, and four were identified only to the family level (Table 1). Members of five families - Alciopidae Ehlers, 1864; Iospilidae Bergström, 1914; Lopadorrynchidae Claparède, 1870; Tomopteridae Grube, 1850; and Typhloscolecidae Uljanin, 1878 - occurred at both stations. The number of species belonging to Alciopidae, Lopadorhynchidae and Typhloscolecidae was greater at the subtropical station than at the subarctic station.

TABLE 1. List of species and families of pelagic polychaetes collected by sediment traps moored at $200 \mathrm{~m}$ of St. K2 (25 July 2013-15 May 2014) in the subarctic and St. S1 (18 July 2013-4 July 2014) in the subtropical western North Pacific.

\begin{tabular}{|c|c|}
\hline $\mathrm{K} 2$ & $\mathrm{~S} 1$ \\
\hline Alciopidae Ehlers, 1864 & Alciopidae Ehlers, 1864 \\
\hline Rhynchonereella angelini (Kinberg, 1866) & Alciopidae sp.1 \\
\hline Iospilidae Bergström, 1914 & Alciopidae sp.2 \\
\hline Iospilidae sp. & Plotohelmis tenuis (Apstein, 1900) \\
\hline Phalacrophorus sp. & Plotohelmis capitata (Greeff, 1876) \\
\hline Lopadorrhynchidae Claparède, 1870 & Rhynchonereella angelini (Kinberg, 1866) \\
\hline Pelagobia sp. & Vanadis crystallina Greeff, 1876 \\
\hline Polynoidae Kinberg, 1856 & Amphinomidae Lamarck, 1818 \\
\hline Polynoidae sp. & Amphinomidae sp. \\
\hline Spionidae Grube, 1850 & Glyceridae Grube, 1850 \\
\hline Spionidae sp. & Glyceridae sp. \\
\hline Tomopteridae Grube, 1850 & Iospilidae Bergström, 1914 \\
\hline Tomopteris (Johnstonella) pacifica (Izuka, 1914) & Phalacrophorus sp. \\
\hline Tomopteris septentrionalis Steenstrup, 1849 & Lopadorrhynchidae Claparède, 1870 \\
\hline Typhloscolecidae Uljanin, 1878 & Lopadorrhynchus uncinatus Fauvel, 1915 \\
\hline Travisiopsis $\mathrm{sp}$ & Maupasia coeca Viguier, 1886 \\
\hline \multirow[t]{7}{*}{ Typhloscolex muelleri Busch, 1851} & Pelagobia sp. \\
\hline & Tomopteridae Grube, 1850 \\
\hline & Tomopteris sp.1 (no tail) \\
\hline & Tomopteris sp.2 (with tail) \\
\hline & Typhloscolecidae Uljanin, 1878 \\
\hline & Travisiopsis sp. \\
\hline & Typhloscolex muelleri Busch, 1851 \\
\hline
\end{tabular}

\section{Community structure}

A cluster analysis divided the samples into two large groups at $26 \%$ similarity, which corresponded with the two geographic stations (K2 vs S1) (Fig. 2). For polychaete species composition, three species groups were identified at $9 \%$ similarity. Differences in species groups were a reflection of abundance patterns at each station. One species group containing Maupasia coeca Viguier, 1886 and Plotohelmis spp. occurred only at St. S1. The largest species group was divided into two species sub-groups: i.e. a species group characterized by high abundance at St. S1 (Pelagobia sp. and Travisiopsis sp.), and a species group with high abundance at St. K2 (Tomopteris spp. and Typhloscolex spp.).

Annual mean polychaete abundance at St. K2 was $5.37 \pm 0.44$ ind. $\mathrm{m}^{-2}$ day $^{-1}$ (mean \pm standard error) and was high from May to August (Fig. 3A). Throughout the year, T. septentrionalis was dominant and accounted for a mean of $62.9 \%$ of total polychaete abundance at this site.

Annual mean polychaete abundance at St. S1 was $1.36 \pm 0.15$ ind. $\mathrm{m}^{-2}$ day $^{-1}$ (mean \pm standard error), and showed no clear seasonal pattern (Fig. 3B). The most abundant species at St. S1 was Pelagobia sp., and this species accounted for a mean of $22.8 \%$ of total polychaete abundance at this site. 


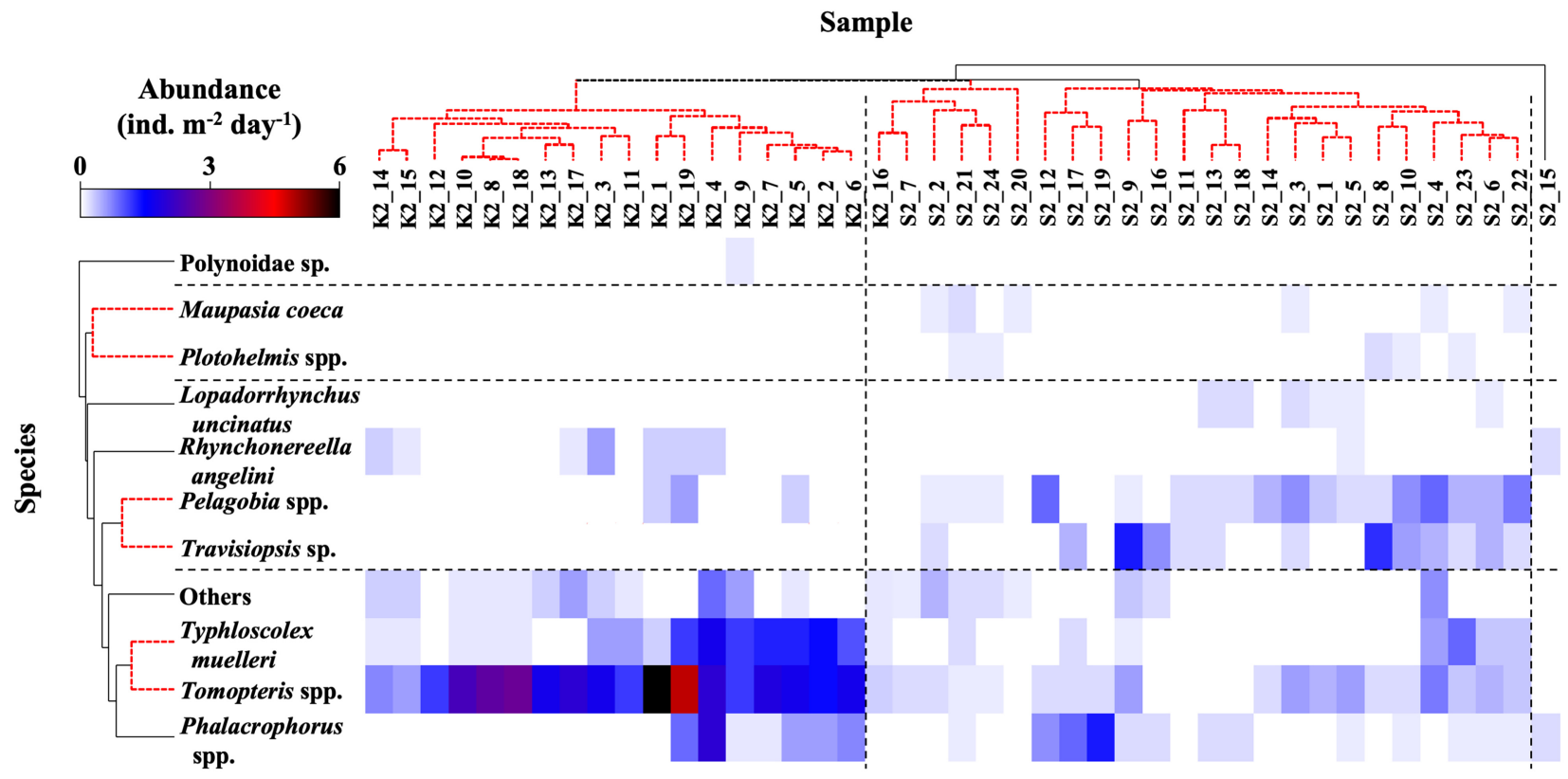

FIGURE 2. Results of cluster analyses on pelagic polychaete abundance at St. K2 (25 July 2013-15 May 2014) in the subarctic and St. S1 (18 July 2013-4 July 2014) in the subtropical western North Pacific. Horizontal and vertical axes indicate groups with samples and species, respectively. Differences in color represent abundance values (ind. $\mathrm{m}^{-2}$ day $^{-1}$ ). Dashed lines demarcate groups.

\section{Population structure}

For the dominant species at St. K2, T. septentrionalis, body length and segment number ranged from 1.9-28.5 $\mathrm{mm}$ and 8-25 segments, respectively (Fig. 4A). Body length of $T$. septentrionalis varied significantly across seasons (one-way ANOVA, $p<0.05$ ). Shorter body length $(<3 \mathrm{~mm})$ individuals and those with few segments $(<10)$ were observed only in winter (December-March).

For the dominant species at St. S1, Pelagobia sp., body length and segment numbers ranged from 0.5-7.1 $\mathrm{mm}$ and 8-20 segments, respectively (Fig. 4B). While seasonal changes in body length of Pelagobia sp. were present (Welch test, $p<0.05$ ), these do not show a clear seasonal pattern, especially with respect to the occurrence of the smaller specimens.

\section{Discussion}

\section{Community structure}

The diversity (as species number) of pelagic polychaetes was higher at the subtropical station (16 species) compared to the subarctic station (10; Table 1). This is similar to the pattern observed in copepods, a predominant component of zooplankton; in this group, species diversity is known to have a clear latitudinal pattern, high in subtropical regions and low in subarctic regions (Rombouts et al. 2009). In benthic polychaetes, Gobin \& Warwick (2006) mentioned that latitudinal patterns of species diversity were unclear, but that species diversity varied with environmental conditions, habitat, and resources.

Polychaete community structure differed between the stations, and three species groups were identified: 1) species occurring only at the subtropical station, 2) species occurring in both regions with high abundance at the subarctic station, and 3) species occurring in both regions but with high abundance at the subtropical station (Fig. 2). We can compare these data with data on the pelagic polychaete community from the eastern North Pacific from the CalCOFI program, which collected from a grid of stations covering $41^{\circ}-21^{\circ} \mathrm{N}$ in the California Current System (Fernández-Alamo et al. 2003). Within these regions, the pelagic polychaete community is reported to be divided into three groups: i.e. northern, southern, and transition communities (Fernández-Alamo et al. 2003). We found three species of Lopadorrhynchidae, at the subtropical station; members of this family are known to be common in warm low latitude oceans (Rouse \& Pleijel 2001). 


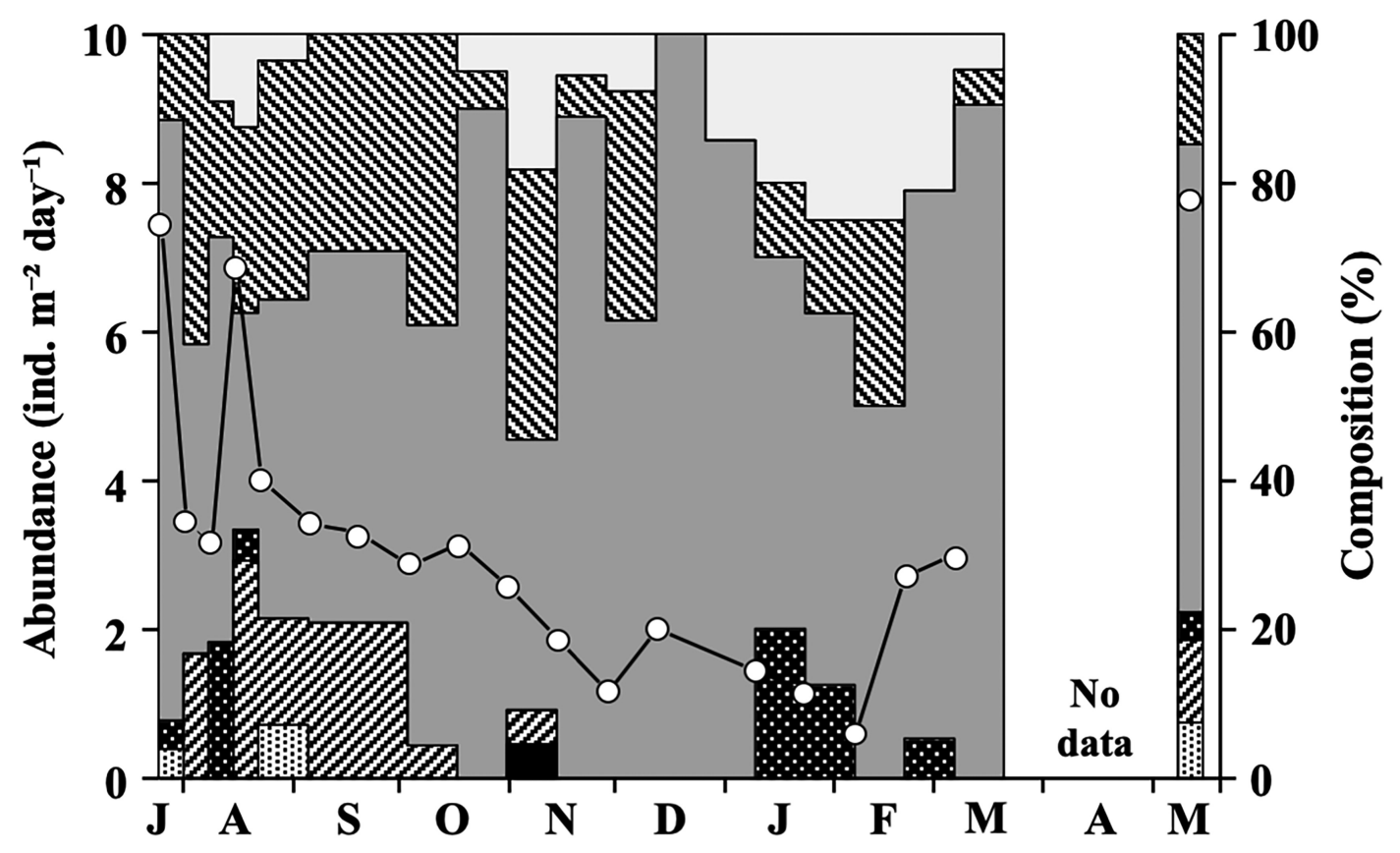

(B) S1

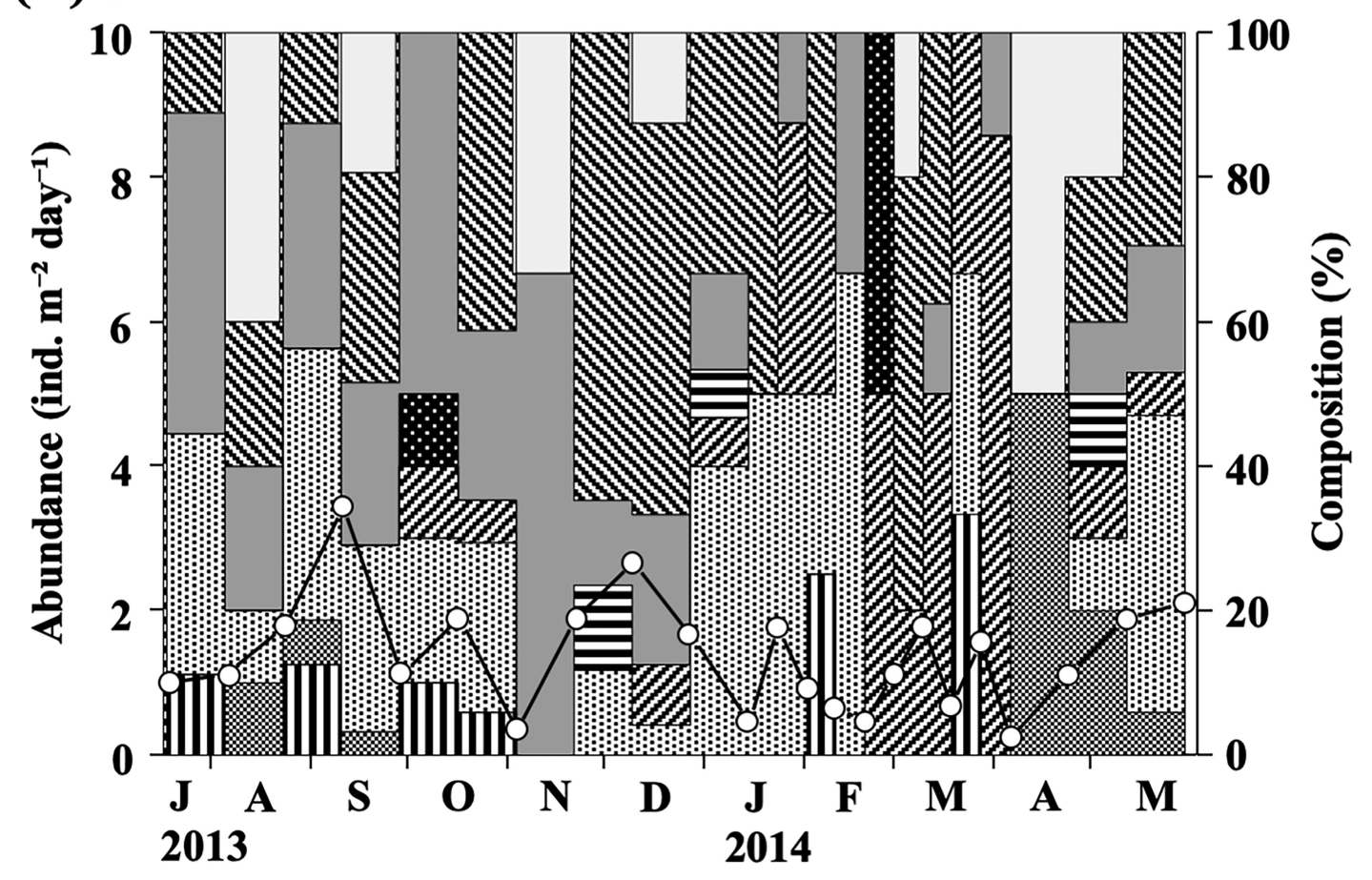

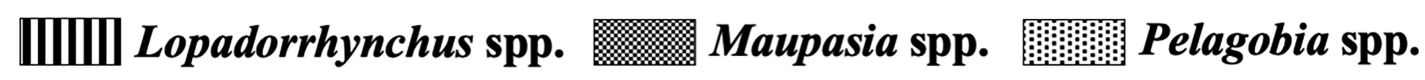

WI/G Phalacrophorus spp. $\equiv$ Plotohelmis spp. Rhynchonereella spp.

$\square$ Tomopteris spp. Typhloscolecidae spp. Polynoidae sp.

$\square$ Others

FIGURE 3. Seasonal changes in abundance and taxonomic composition of pelagic polychaetes at St. K2 in the subarctic (25 July 2013-15 May 2014) (A) and St. S1 in the subtropical (18 July 2013-4 July 2014) (B) western North Pacific. 
The annual mean abundance of pelagic polychaetes was greater at the subarctic station than at the subtropical station, by a factor of 3.9 times (Fig. 3). Concerning seasonality, polychaetes were more abundant in May to August at the subarctic statin, where they were dominated in abundance by $T$. septentrionalis (composed 63\% in annual mean abundance). In contrast, they showed less seasonality at the subtropical station, with lower abundance of the dominant species (Pelagobia sp.; 23\%). Similar patterns are reported for the California Current System: the abundance of pelagic polychaetes at depths of 0-200 $\mathrm{m}$ is higher for the northern community (mean: 242.0 ind. $1000 \mathrm{~m}^{-3}$ ), and lower for the southern $\left(75.6 \mathrm{ind} .1000 \mathrm{~m}^{-3}\right)$ and transition $\left(4.6 \mathrm{ind} .1000 \mathrm{~m}^{-}\right.$ $\left.{ }^{3}\right)$ zones (Fernández-Alamo et al. 2003). Dominance of $T$. septentrionalis in the northern community is also reported (Fernández-Alamo et al. 2003). This indicates that similar latitudinal patterns in pelagic polychaete abundance and common dominant species are present for the eastern and western North Pacific.

While polychaete abundance differed between the two stations $(p<0.05$, Mann-Whitney $U$-test $)$, the abundance and biomass of polychaetes as a fraction of the total zooplankton community did not differ between subarctic and subtropical station (Yokoi et al. 2018). Zooplankton abundance and biomass are well known to be greater in the subarctic than in the subtropics (Longhurst 1998). This was true at our stations: zooplankton was higher in both abundance (2.3 times) and biomass ( 6.8 times) at the subarctic station compared to the subtropical station (Yokoi et al. 2018). These facts suggest that the regional differences in polychaete abundance observed by Fernández-Alamo et al. (2003) and this study may be related to regional differences in zooplankton standing stock.

The dominant species at the subarctic station, T. septentrionalis, is known to occur broadly in the northern North Pacific (Dales, 1957). Seasonal patterns of polychaete abundance at this station (Fig. 3A) are likely related to clear seasonal patterns in both primary production and zooplankton abundance in the subarctic Pacific (Longhurst 1998). Planktonic chaetognaths have been reported as prey items for Tomopteris spp. from various locations (Lebour 1923; Rakusa-Suszczewski 1968; Fauchald \& Jumars 1979). In the present study, there was no correlation between the abundance of polychaetes and chaetognaths in the same zooplankton swimmer samples $(r=0.023-0.054)$. This fact suggests that the seasonality of polychaete abundance in the subarctic region has no direct relationship with the seasonality of chaetognaths in the same region.

\section{Population structure}

Segment number of Tomopteris spp. is known to increase with increasing body length (Åkesson 1962). In this study, specimens of T. septentrionalis with 8-25 segments were observed, and segment number increased with increasing body length (Fig. 4A). For population structure, significant seasonal changes in body length were detected, and smaller individuals ( $<3 \mathrm{~mm}$ body length and $<10$ segments) occurred only in winter (DecemberMarch) (Fig. 4A). This suggests that the main reproductive period of T. septentrionalis at this location might be in winter.

(A) K2: Tomopteris septentrionalis

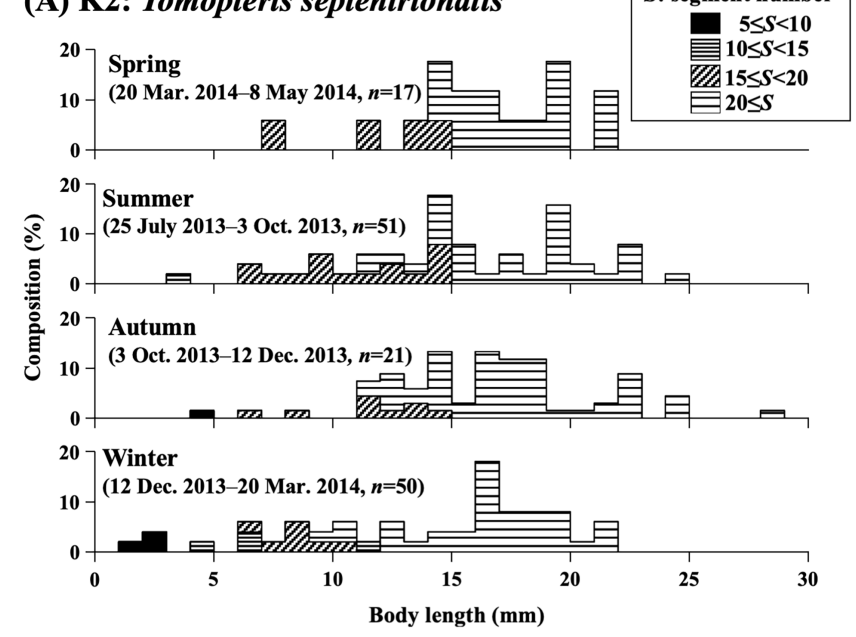

(B) S1: Pelagobia sp.

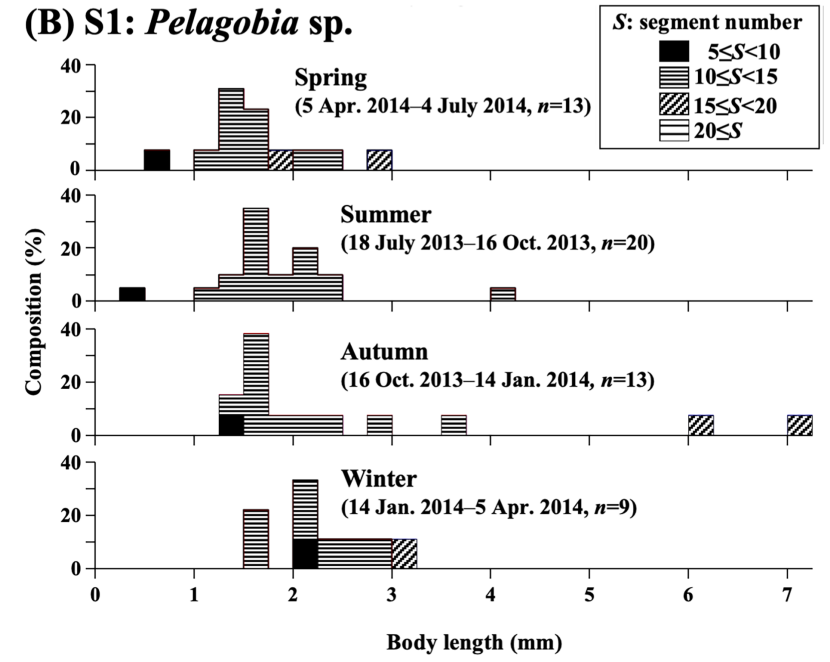

FIGURE 4. Seasonal changes in body length of (A) Tomopteris septentrionalis at St. K2 in the subarctic and (B) Pelagobia sp. at St. S1 in the subtropical western North Pacific. Column patterns indicate differences in segment number. 
Large individuals of Tomopteris spp. are primary carnivores (Jumars et al. 2015). Copepods composed $50 \%$ of abundance and $60 \%$ of the biomass in the zooplankton swimmer samples here examined (Yokoi et al. 2018). Copepods may be a food source of T. septentrionalis. However, we detected no correlation was detected between the abundances of polychaetes and copepods $(r=0.196, p=0.394)$. Small Tomopteris spp., are reported to ingest diatoms as an important dietary component (Hopkins 1985, Hopkins \& Torres 1989, Jumars et al. 2015). Since phytoplankton in the subarctic Pacific bloom saround April-May (Longhurst 1998), reproduction of $T$. septentrionalis in winter (December-March) might match early juvenile development with the spring phytoplankton bloom. Analyses of gut contents and stable isotope composition may valuable to test this hypothesis (Jumars et al. 2015).

The dominant polychaete at the subtropical station, Pelagobia sp., is reported to be a primary herbivore, feeding on phytoplankton (Day 1967; Hopkins 1985, 1987; Hopkins \& Torres 1989). Since the sediment trap of this study was moored at $200 \mathrm{~m}$ depth, it might be difficult to feed on fresh phytoplankton at that depth. In the subtropical North Pacific, the nutrients are depleted at shallower depths, and pico-sized phytoplankton (Prochlorococcus) form a sharp peak around $100 \mathrm{~m}$ depth which corresponds with the nutrient-cline at that depth (Furuya 1990; Campbell et al. 1994). Considering this, the food for Pelagobia sp. might be provided through the microbial loop (picophytoplankton - heterotrophic nanoflagellates [HNF] - ciliates) in the subtropical North Pacific. In the present study, no clear seasonal pattern was not detected for the population structure of Pelagobia sp. at the subtropical site (Fig. 4B). In the subtropical North Pacific, primary productivity is known to be aseasonal (Longhurst 1998), and this may partially explain the lack of seasonality in the population structure of Pelagobia sp.

\section{Acknowledgments}

The sediment trap samples used in this study were moored and recovered by R/V Mirai of JAMSTEC. Part of this study was supported by a Grant-in-Aid for Scientific Research 20H03054 (B), 19H03037 (B) and 17H01483 (A), and Challenging Research (Pioneering) 20K20573 from the Japan Society for the Promotion of Science (JSPS). This work was partially conducted for the Arctic Challenge for Sustainability II (ArCS II) project.

\section{References}

Accornero, A., Manno, C., Esposito, F. \& Gambi, M.C. (2003) The vertical flux of particulate matter in the polynya of Terra Nova Bay. Part II. Biological components. Antarctic Science, 15, 175-188.

https://doi.org/10.1017/S0954102003001214

Åkesson, B. (1962) The embryology of Tomopteris helgolandica (Polychaeta). Acta Zoologica, 43, 135-199. https://doi.org/10.1111/j.1463-6395.1962.tb00070.x

Blake, J.A. (2017) Larval development of Polychaeta from the northern California coast. Fourteen additional species together with seasonality of planktic larvae over a 5-year period. Journal of the Marine Biological Association of the United Kingdom, 97, 1037-1049. https://doi.org/10.1017/S0025315417000716

Campbell, L., Nolla, H.A. \& Vaulot, D. (1994) The importance of Prochlorococcus to community structure in the Central North Pacific Ocean. Limnology and Oceanography, 39, 954-961. https://doi.org/10.4319/lo.1994.39.4.0954

Dales, K.P. (1957) Pelagic polychaetes of the Pacific Ocean. Bulletin of the Scripps Institution of Oceanography, 7, 95-167.

Day, J.H. (1967) A monograph on the Polychaeta of Southern Africa. British Museum of Natural History, London, 656, 1-878. https://doi.org/10.5962/bhl.title.8596

Fauchald, K. \& Jumars, P. (1979) The diet of worms: a study of polychaete feeding guilds. Oceanography and Marine Biology: an Annual Review, 17, 193-284.

Feigenbaum, D. (1979) Predation on chaetognaths by typhloscolecid polychaetes: one explanation for headless specimens. Journal of the Marine Biological Association of the United Kingdom, 59, 631-633. https://doi.org/10.1017/S0025315400045641

Fernández-Alamo, M.A., Sanvicente-Añorve, L. \& Alatorre-Mendieta, M.A. (2003) Changes in pelagic polychaete assemblages 
along the California current system. Hydrobiologia, 496, 329-336.

https://doi.org/10.1023/A:1026125705526

Furuya, K. (1990) Subsurface chlorophyll maximum in the tropical and subtropical western Pacific Ocean: vertical profiles of phytoplankton biomass and its relationship with chlorophyll $a$ and particulate organic carbon. Marine Biology, 107, 529-539. https://doi.org/10.1007/BF01313438

Giangrande, A. (1997) Polychaete reproductive patterns, life cycles and life histories: An overview. Oceanography and Marine Biology: an Annual Review, 35, 323-386.

Gobin, J.F. \& Warwick, R.M. (2006) Geographical variation in species diversity: A comparison of marine polychaetes and nematodes. Journal of Experimental Marine Biology and Ecology, 330, 234-244. https://doi.org/10.1016/j.jembe.2005.12.030

Guglielmo, R., Gambi M.C., Granata, A., Guglielmo, L. \& Minutoli, R. (2014) Composition, abundance and distribution of holoplanktonic polychaetes within the Strait of Magellan (southern America) in austral summer. Polar Biology, 37, 9991015. https://doi.org/10.1007/s00300-014-1496-8

Halanych, K.M., Cox, L.N. \& Struck, T.H. (2007) A brief review of holopelagic annelids. Integrative and Comparative Biology, $47,872-879$. https://doi.org/10.1093/icb/icm086

Honda, M.C. (2016) Short introduction to the K2S1 project. Journal of Oceanography, 72, 341-342. https://doi.org/10.1007/s10872-016-0375-z

Honda, M.C., Kawakami, H., Matsumoto, K., Wakita, M., Fujiki, T., Yoshihisa, M., Sukigara, C., Kobari, T., Uchimiya, M., Kaneko, R. \& Saino, T. (2016) Comparison of sinking particles in the upper $200 \mathrm{~m}$ between subarctic station K2 and subtropical station S1 based on drifting sediment trap experiments. Journal of Oceanography, 72, 373-386. https://doi.org/10.1007/s10872-015-0280-x

Hopkins, T.L. (1985) Food web of an Antarctic midwater ecosystem. Marine Biology, 89, 197-212. https://doi.org/10.1007/BF00392890

Hopkins, T.L. (1987) Midwater food web in McMurdo Sound, Ross Sea, Antarctica. Marine Biology, 96, $93-106$. https://doi.org/10.1007/BF00394842

Hopkins, T.L. \& Torres, J.J. (1989) Midwater food web in the vicinity of a marginal ice zone in the western Weddell Sea. DeepSea Research, 36, 543-560. https://doi.org/10.1016/0198-0149(89)90005-8

Jumars, P.A., Dorgan, K.M. \& Lindsay, S.M. (2015) Diet of worms emended: An update of polychaete feeding guilds. Annual Review of Marine Science, 7, 497-520. [Supplemental appendix: Family-by-family updates] https://doi.org/10.1146/annurev-marine-010814-020007

Lebour, M.V. (1923) The food of plankton organisms. II. Journal of the Marine Biological Association of the United Kingdom, $13,70-92$. https://doi.org/10.1017/S0025315400010936

Longhurst, A. (1998) Ecological Geography of the Sea. Academic Press, San Diego, U.S.A., 398 pp.

Matsuno, K., Yamaguchi, A., Fujiwara, A., Onodera, J., Watanabe, E., Imai, I., Chiba, S., Harada, N. \& Kikuchi, T. (2014) Seasonal changes in mesozooplankton swimmers collected by sediment trap moored at a single station on the Northwind Abyssal Plain in the western Arctic Ocean. Journal of Plankton Research, 36, 490-502. https://doi.org/10.1093/plankt/fbt092

Ohashi, R., Ishii, K., Fujiki, T., Kitamura, M., Matsumoto, K., Honda, M.C. \& Yamaguchi, A. (2011) Short-term changes in the planktonic community of the western subarctic Pacific during early summer: analysis of sediment trap samples. Bulletin of the Plankton Society of Japan, 58, 123-135.

Øresland, V. (1990) Feeding and predation impact of the chaetognath Eukrohnia hamata in Gerlache Strait, Antarctic Peninsula. Marine Ecology Progress Series, 63, 201-209. https://doi.org/10.3354/meps063201

Rakusa-Suszczewski, S. (1968) Predation of Chaetognatha by Tomopteris helgolandica Greff. ICES Journal of Marine Science, $32,226-231$. https://doi.org/10.1093/icesjms/32.2.226

Rombouts, I., Beaugrand, G., Ibaňez, F., Gasparini, S., Chiba, S. \& Legendre, L. (2009) Global latitudinal variations in marine copepod diversity and environmental factors. Proceedings of the Royal Society B, 276, 3053-3062.

https://doi.org/10.1098/rspb.2009.0742

Rouse, G.W. \& Pleijel, F. (2001) Polychaetes, Oxford University Press, Oxford, 384 pp. 
Uttal, L. \& Buck, K.R. (1996) Dietary study of the midwater polychaete Poeobius meseres in Monterey Bay, California. Marine Biology, 125, 333-343. https://doi.org/10.1007/BF00346314

Yasuda, I. (2003) Hydrographic structure and variability in the Kuroshio-Oyashio transition area. Journal of Oceanography, 59, 389-402. https://doi.org/10.1023/A:1025580313836

Yokoi, N., Abe, Y., Kitamura, M., Honda, M.C. \& Yamaguchi, A. (2018) Comparisons between POC and zooplankton swimmer flux from sediment traps in the subarctic and subtropical North Pacific. Deep-Sea Research I, 133, 19-26. https://doi.org/10.1016/j.dsr.2018.01.003 